\title{
Do Intergroup Threats Provoke Intergroup Anxiety? An Experimental Study on Chinese Ethnic Group in Indonesia
}

\author{
Gabrielle Irene \& Sutarimah Ampuni* \\ Fakultas Psikologi, Universitas Gadjah Mada, D. I, Yogyakarta
}

\begin{abstract}
Through an online experiment, this study examines the role of intergroup threat on intergroup anxiety in Indonesian Chinese ethnic group, by considering the moderating role of positive intergroup contact. The posttest-only randomized experimental design was used in this study. Sixtyfour Chinese Indonesian college students (male $=31$, female $=33$ ) were randomly assigned into treatment group (male $=14$, female $=18$ ) and control group (male $=17$, female = 15). All participants were first asked to complete a positive intergroup contact scale. Following this, participants in the treatment group were asked to read threat-inducing reading passages, while those in the control group were given neutral reading passages. They then were asked to complete a manipulation check and intergroup anxiety scale. Data were analyzed using analysis of covariance (ANCOVA). Results showed that when positive intergroup contact was controlled, intergroup threat significantly affected intergroup anxiety but in the direction opposing the hypothesis. Instead of showing higher intergroup anxiety, the experimental group showed lower intergroup anxiety compared to the control group. An interview on a few participants was conducted to explore possible explanations of this result.
\end{abstract}

Keywords: intergroup anxiety, intergroup threat, intergroup contact, Chinese Indonesian

\begin{abstract}
Abstrak
Penelitian ini merupakan eksperimen yang dilakukan secara daring dan bertujuan untuk mengetahui pengaruh intergroup threat terhadap intergroup anxiety pada kelompok etnis Tionghoa di Indonesia dengan mempertimbangkan positive intergroup contact sebagai moderator. Posttest-only randomized experimental design digunakan dalam eksperimen ini. Sebanyak 64 subjek (laki-laki $=31$; perempuan $=33$ ) dibagi ke dalam kelompok eksperimen (lakilaki = 14; perempuan =18) dan kelompok kontrol (laki-laki = 17; perempuan =15). Prosedur eksperimen diawali dengan meminta subjek untuk mengisi skala positive intergroup contact. Subjek dalam kelompok eksperimen kemudian menerima perlakuan berupa bacaan yang membangkitkan intergroup threat, sementara subjek dalam kelompok kontrol menerima bacaan netral. Setelah menerima perlakuan, subjek diminta untuk mengisi manipulation check dan skala intergroup anxiety. Data diolah menggunakan metode analisis kovarians (ANAKOVA). Hasil penelitian menunjukkan intergroup threat mempengaruhi intergroup anxiety secara signifikan, namun dalam arah yang berkebalikan dengan hipotesis. Alih-alih memiliki intergroup anxiety yang lebih tinggi, kelompok eksperimen menunjukkan skor intergroup anxiety yang lebih rendah daripada kelompok kontrol. Review literatur lanjutan dan wawancara kepada beberapa subjek dilakukan untuk menyelidiki alasan-alasan yang mungkin dapat menjelaskan hasil eksperimen ini.
\end{abstract}

Kata kunci: kecemasan antarkelompok, ancaman antarkelompok, kontak antarkelompok, etnis Tionghoa Indonesia

\section{Introduction}

Intergroup anxiety is the feeling of anxiety and discomfort that a person feels when interacting with their out-group community (Stephan \& Stephan, 1985). These feelings of anxiety and discomfort may present in individuals from both majority and minority groups (Islam \& Hewstone,

Naskah masuk: 11 Desember 2019

Naskah diterima: 3 Juli 2020
1993) as a consequence of the existence of intergroup emotions (Mackie et al., 2000). Someone with high intergroup anxiety may feel restless, distressed, and uneasy during intergroup interactions. One of the reasons for this distress is because they tend to view out-group members as less similar to themselves and thus expect a more difficult interaction with out-group members

*Fakultas Psikologi, Universitas Gadjah Mada Jl. Sosio Humaniora Bulaksumur, D. I. Yogyakarta, 55281 E-mail: ampuni@ugm.ac.id 
compared to in-group members (Britt et al., 1996). Intergroup anxiety also amplifies the activation of evaluative racial bias, making intergroup interaction even more difficult (Amodio \& Hamilton, 2012). Physiologically, intergroup anxiety can increase one's systolic blood pressure and cortisol level when anticipating intergroup interactions with their out-group members, which may manifest in non-verbal behavior such as closed body language and tense facial expressions when interacting with out-groups (Littleford et al., 2005; Trawalter et al., 2012).

Intergroup anxiety may lead to a counterproductive effect on intergroup relationships. It may cause group members, both majority and minority groups, to focus their mind on the negative consequences they may receive when engaging in intergroup interactions (Shelton \& Richeson, 2006). This may further lead to intergroup bias and negative attitudes towards out-group members and even cause avoidance towards out-groups and reluctance to help out-groups (Stephan, 2014).

One of the biases against out-groups caused by intergroup anxiety is the perception bias against out-group diversity or perceived out-group variability. Each group certainly consists of many individuals with diverse traits and characters (Islam \& Hewstone, 1993). However, a person with higher intergroup anxiety tends to find it difficult to see this diversity and leads to generalizing all out-group members with the community stereotypes (Hutchison \& Rosenthal, 2011). A meta-analysis that reviewed 95 studies of intergroup threat and out-group attitudes concludes that intergroup anxiety was found to be a strong and consistent predictor of out-group attitudes, where people with higher intergroup anxiety tend to show negative out-group attitudes such as prejudice or stronger stereotypes against his out-groups (Riek et al., 2006).

Riek et al. (2006) stated that intergroup anxiety may arise from the perception that there are threats from out-groups, usually referred to as an intergroup threat. Theoretically, intergroup threat consists of two components, namely, realistic threat and symbolic threat. When a person feels that another group is in a position that can harm him physically and materially, then he is experiencing a realistic threat. An example is when there is an anti-Chinese riot happening, a person of Chinese ethnicity may feel that their life and safety are being threatened. On the other side, if the person feels that the other group threatens him symbolically and non-materially then he is experiencing a symbolic threat. The example is when a White person feels that a Black family moving to their White neighborhood would bring Black values into their daily life and that this would threaten the purity of his White values.
Stephan, Ybarra, and Morrison (2009) argued that one's perception of intergroup threat is more important and impactful than the factual intergroup threat happening in a society. A perceived intergroup threat has real consequences even though it is neither accurate nor factual. A study conducted in Germany (Semyonov et al., 2004) revealed that the real proportion of immigrants (factual threat) in some German provinces did not predict native German's discriminative behavior. On the other hand, native German's perceived immigrant proportion evidently predicted their discriminative behavior towards immigrants. Another study by Davis and Stephan (2011) using the technology of facial electromyography found that participants who received an individual-level, intergroup threat through a short video responded with greater activity in a facial muscle (frontalis) that is associated with inwardly directed emotions (such as fear, anxiety); whereas participants who received a group-level threat, also given through a short video, responded with greater activity in a facial muscle (corrugator) that is associated with outwardly directed emotions (anger, frustration).

Positive intergroup attitudes and behaviors could be seen as a marker of harmonious intergroup relations in the society, thus it is very important to maintain. As intergroup anxiety has consistently been shown as a strong predictor of intergroup attitudes and mediator of various motives and behavior in intergroup relationships, it is important to study this variable in an effort of maintaining and improving the harmony of intergroup relations in the society.

\section{Intergroup anxiety in the context of Chinese ethnic group in Indonesia}

In a highly multicultural country like Indonesia, the harmony of intergroup relationships within society is an essential element for the stability of the nation. However, history reveals that intergroup relationships, including those between the Indonesian Chinese ethnic group and its Indonesian native counterpart, have not always been that harmonious. Conflicts have arisen in many stages of the country's history, starting from the conflict between the colonial power versus Chinese ethnic locals resulting in the riot called Geger Pacinan in 1740, Chinese ethnic massacre during Perang Jawa (1825-1830), Anti-Chinese riots around Indonesia nearing the end of The Old Order (1950-1965), May 1998 riot nearing the end of The New Order, up to the recent Anti-Chinese nuanced turmoil around gubernatorial and presidential elections in Indonesia (2014-2019) (Dhani, 2016; Kwartanada, 2015; Suryadinata, 2019). 
It seems that although the history of Chinese descendants in Indonesia could be traced back to the early centuries, the stories of their presence in Indonesia were always a tale of bumpy roads. Up to recent years, Chinese descendants in Indonesia still continue to face hardships in living their lives in between Indonesian society. Constitutionally, people of Chinese ethnicity in Indonesia were once not allowed to express their culture freely under the 1967 law; they were strongly encouraged to change their Chinese birth name into Indonesian name as their formal name (Keputusan Presiden Republik Indonesia, 1967).

Three years after the 1998 riots, President Abdurrahman Wahid reformed the law related to the cultural expression of Chinese ethnicity. The repressive act was abolished and replaced by a new act where Chinese ethnic Indonesians are free to carry out their traditions, religions, and customs in Indonesia including having Chinese names and conducting ceremonies such as the Chinese Lunar New Year celebration (Aziz, 2016). This has been a major step of the Indonesian government in granting rights and recognition and eliminating discrimination against Chinese ethnicity as a minority group. However, these changes did not immediately improve intergroup relations between Chinese Indonesians and indigenous Indonesians. Although intergroup threat in the form of constitutional discrimination had been ended, prejudice and intergroup anxiety were not readily eliminated just by the amendment of regulation. In fact, the relationships between these two groups have been increasingly tainted with great distrust and religious teaching-backed hatred in recent years. This is evident in a recent study when Putra (2016), through his discourse analysis study, found that being labeled as the "other" (non-Muslim and nonindigenous), a Chinese Indonesian citizen is perceived to be unfit to become the governor of Jakarta for the reason that "he may disgrace the nation".

The link between intergroup threatsboth the realistic and the symbolic ones-and intergroup anxiety as described previously could be very clearly seen through the long winding history of Chinese ethnic and indigenous Indonesians relationships illustrated above. We have known previously from Davis and Stephan (2011) that perceiving intergroup threats could induce inwardly-focused emotions (e.g., fear, anxiety). Even though these emotions can actually serve as nonverbal signals that a threat exists and prepare the body for stress, in reality, they usually motivate the threatened individual to escape from the perceived threatening situations (Davis \& Stephan, 2011; Stephan, Renfro, \& Davis, 2008). During antiChinese conflicts throughout Indonesian history, one of the visible patterns of behavior in Chinese ethnic Indonesians is avoiding contact with native
Indonesians. During the 1967 anti-Chinese riots in West Kalimantan which claimed hundreds of fatalities, for example, tens of thousands of Chinese descendant Indonesians fled to the city of Pontianak and Singkawang, where they were the majority compared to native Indonesians of Dayak and Malay ethnicities. The more recent one, during the May 1998 riots, Chinese Indonesians responded the threat from the riots by fleeing outside the country or the cities to hide (Isnaeni, 2010). These exoduses indicate the rising anxieties as a result of the threatening situations.

\section{The effect of intergroup contact}

It is interesting to see what factors could strengthen or weaken the influence of perceived intergroup threat against intergroup anxiety. According to the theory of intergroup anxiety (Stephan \& Stephan, 1985), individuals who often make contact and interaction with their out-groups tend to have a lower intergroup anxiety than individuals who rarely interact with out-group members. This theory is similar to the hypothesis of contacts by Allport (1954), who proposed that higher intergroup contact could influence the intergroup attitudes in a more positive direction.

In support of the above theory, a metaanalysis study conducted by Pettigrew and Tropp (2008) confirmed these theories and found that high intergroup contacts decrease intergroup anxiety. In line with that, Aberson (2015) found a negative relationship between positive intergroup contactand intergroup anxiety. Research by Paolini et al. (2004) in Northern Ireland also found that through the mediation of reduced intergroup anxiety, intergroup friendships were proven to lead to reduced intergroup prejudice. This research was conducted in the context of the relationship between Protestant and Catholic groups in Ireland which has a long history of conflict. Hutchinson and Rosenthal (2011) also found that mediated by intergroup anxiety, repeated high-quality contact with Muslims predicted more positive out-group attitudes, higher perceived out-group variability and more positive behavioral intentions by NonMuslims in London.

It is thus reasonable to expect that positive intergroup contact would contribute as the moderating variable that may reduce the effect of intergroup threat on intergroup anxieties. Through intergroup contact, one gets the opportunity to recognize and understand the behavior, traits, beliefs, and values of the outgroup members. Lack of experience of intergroup contacts hinders an individual's chance of acquiring skills in interacting as well as knowing his out-group members individually. In the end, this lack of interaction skills and knowledge about the out-groups leads 
to increasing intergroup anxiety (Allport, 1954; Pettigrew \& Tropp, 2008).

\section{The present study}

Based on the above explanations, intergroup anxiety is a type of anxiety one feels when anticipating interactions with members of their out-groups which is theorized to be influenced by a perceived threat and intergroup contacts along with many other factors. Intergroup anxiety is known to consistently mediate various stimuli in predicting intergroup attitudes such as prejudice, perceived out-group variability, and positive behavioral intentions toward out-groups. Positive intergroup attitude is an important variable for harmonious relationships within a society. On the other hand, history has recorded that the relationships between Chinese and native Indonesians have been loaded with negative intergroup attitudes and behaviors that repeat in different forms and styles as time goes by. It is now becoming an urgent and long overdue homework for Indonesia to openly study these intergroup relations in order to improve the quality of the relationships.

Works of literature and studies about Chinese Indonesian topics are actually quite large in number; a lot of these studies are in the area of politics, culture, history, and intergroup dynamics. For instance, Mustamin (2006) found that the risk of dispute between Chinese Indonesians and indigenous people in Makassar was likely to be triggered by prejudice that Chinese ethnicity dominated the economy while indigenous people dominated the politics. Other studies highlighted that some historic factors might contribute to the disharmony between Javanese and Chinese ethnicity, where Chinese Indonesians are believed to inherit a higher social hierarchy than the Javanese (Prihartanti et al., 2009; Sanjatmiko, 1993). Another study found that jealousy and stereotypes of the Chinese Indonesians as stingy, cheaters, suspicious, and sloppy have caused resentment on the natives (Rahman, 2013; Suryadinata, 2002). Nevertheless, studies about Chinese Indonesians' intergroup relationships with its Native Indonesian counterpart which examines the dynamics of intergroup contact, perceived threat, and intergroup anxiety have not been done before. It is critical to start doing more research from a social psychological perspective. This research examines whether intergroup anxiety in Chinese ethnic Indonesians is affected by perceived intergroup threat and whether intergroup contact moderates the link between intergroup threat and intergroup anxiety.

\section{Materials and Methods}

\section{Participants}

Participants were Indonesian college students of Chinese ethnicity from universities in Java Island (the main island) aged 18-24 years old. Subjects were recruited through announcements broadcasted in social media such as Path, Facebook, Twitter, Whatsapp, and Line and through a network of researchers. The announcement explained the research aim in an inexplicit term (i.e., "this research is aimed to study some aspects of Chinese Indonesian life in their societies"). Criteria for eligible participants and the researcher's contact number are provided. A total of 76 prospective subjects expressed their interest to participate by contacting the researcher, but in the subsequent process, 12 people withdrew. The final number of subjects participating in this experiment was 64 (male $=31$, female $=33$ ). They were asked to sign an informed consent for their participation and were included in a draw to win phone credit as a reward after their participation. They were debriefed with the actual aim of the study after data collection has finished.

\section{Research design}

This study is an experimental study with a posttest-only design. Subjects were divided into two groups randomly using an online randomizer (RANDOM.ORG). The experimental group received an intergroup threat induction, while the control group did not receive intergroup threat induction. The design and procedure of this study can be represented using the following diagram: 
$\mathrm{R}$

$\mathrm{R}$

\begin{tabular}{lllll}
$E$ & $P$ & $X$ & $M$ & 0 \\
\hline$K$ & $P$ & $-X$ & $M$ & 0
\end{tabular}

Description:
1. $\mathrm{R}$
: Random Assignment
2. E
: Experimental Group
3. $\mathrm{K}$
: Control Group
4. P
: Measurement of Positive Intergroup Contact scale
5. X
: Intergroup Threat induction (Reading material contains realistic-symbolic threat)
6. $-\mathrm{X}$
7. $\mathrm{M}$
: Neutral reading material
: Manipulation Check Measurement
8. 0
: Measurement of Intergroup Anxiety scale

Treatment

Five reading passages were used in this experiment. To induce intergroup threat, two reading passages which include intergroup threats as narration were given to participants in the experimental group. Both of these readings were composed by the researchers and were written in a snippet format as if they were news taken from an online media portal. Both realistic threat and symbolic threat were inserted in the "news." The first reading passage was entitled Demo Glodok ("The Glodok Protest") which reported a protest carried out by an indigenous community ('Community X') that demanded the government to revive the New Order regulation related to Chinese ethnicity. This community believed that since the Chinese Indonesians were given the freedom to embrace their belief and culture, they had become arrogant and abusive against indigenous Indonesians. This reading contained mostly realistic aspects of intergroup threats. The second reading material was entitled Boikot Usaha Tionghoa di Kota A ("Boycott the Chinese business at the City of $A$ ") contained mostly symbolic intergroup threats. Both reading materials had undergone expert judgments by two scholars in the field of social psychology and one scholar in the field of experimental psychology.

Apart from the two reading passages containing threats, three other neutral reading materials were also prepared for this experiment. These three passages were taken from Indonesian online media portals, BeritaSatu and Detik, and did not contain any information about specific ethnic groups. The first neutral reading material was entitled Keluarga Judika ("The family of Judika") (Octama, 2016) which contained news about Judika, a celebrity who was enjoying his role as a father. The second material was entitled Metode 5S ("The method of 5S") (Kinanti, 2016) which discussed five methods of maintaining health, and the third reading was entitled Program \#InternetBaik ("The program of \#GoodInternet")
(Herman, 2016) which reported a program to build a positive and constructive digital ecosystem. The experimental group in this study received both reading passages with intergroup threat induction (Demo Glodok and Boikot Usaha Tionghoa di Kota $A$ ), plus one neutral reading (Metode 5S). This neutral reading was given to the experimental group to disguise the treatment, i.e. so that the subjects do not suspect that they are being treated. Meanwhile, the control group received three placebo readings, including Metode 5S, Keluarga Judika, and Program \#InternetBaik.

Every time they finished reading one passage, subjects were asked to answer two questions related to the passage. These questions were aimed to ensure that the subjects read the passage carefully. After reading the entire materials and answering all the questions related to all readings, subjects were then presented with a manipulation check scale.

\section{Measurements}

Measurement tools in this study consisted of a manipulation check, intergroup anxiety scale, and positive intergroup contact scale.

The manipulation check scale contained three questions to check whether the reading passages did induce the participants' general anxiety (in the experimental group). The question for this manipulation check scale was: "What do you feel after reading the three recently-presented readings?" These questions were answered by rating to what extent they feel sad, happy (unfavorable), and anxious after reading, by giving a rating between 1 (Not at all) to 5 (Very).

Intergroup Anxiety scale (13 items, $\alpha=$ 0.954) was adapted from Stephan and Stephan (1985). This scale measures the anxiety that may arise within the individual when he/she interacts between groups; namely fear, worry, feeling threatened, awkwardness, anxious (all are favorable), friendly, comfortable, trusting, confident, safe, and relaxed (all are reverse-coded). We 
added another item that is "irritated", which is based on the researcher's observation and personal experience accurately describes intergroup anxiety in Indonesia. Participants were asked to imagine a situation when they have to work in a team consisting of only non-Chinese indigenous Indonesians whom they have never known before ("Imagine a situation when you have to work in a team. The team consists of only non-Chinese indigenous Indonesians whom you have never known before. How do you feel? Write your response in the scale below"). Then they were asked to state how they would feel by choosing the options in the scale ranging from "strongly disagree" to "strongly agree". The scale we used in the study can be seen in Appendix 1.

Positive intergroup contact scale (20 items, $\alpha=0.928$ ) was adapted from Dhont and Van Hiel (2012). We modified the original scale by adding specific periods of life (from kindergarten to college). Thus, our question was modified into (for example): "When you were in kindergarten, your contacts generally with indigenous Indonesians (non-Chinese) were... (friendly, joyful, constructive, and rewarding)". Participants were asked to respond to the items using a Likert scale ranging from Strongly Disagree (1) to Strongly Agree (5). The total score was calculated by summing the scores of the four items. This scale is available in Appendix 2.

\section{Data analysis}

One Way Analysis of Covariance (oneway ANCOVA) was used to compare posttest scores of intergroup anxiety in the experimental and control group by controlling positive intergroup contact as the covariate. After the data analysis was performed, we also conducted interviews with some subjects to investigate the possible reasons that might explain the results of this study.

\section{Results}

The scores of intergroup anxiety, intergroup contact, and manipulation check are shown in Table 1. It can be seen that the manipulation check scores ranged between 7 (minimum) to 15 (maximum) for the experimental group and 3 (minimum) to 9 (maximum) for the control group. T-test for manipulation check showed significant differences between control and experimental groups $(t(62)=-8.883, p<.001)$. The experimental group showed a higher score of manipulation check than the control group, thus the treatment of threat-inducing passage did induce the participants' feelings of anxiety and sadness.
ANCOVA showed a significant difference in intergroup anxiety between the control group and the experimental group after controlling the positive intergroup contact $(F(1.62)=4.46, p$ $=.036)$. However, contrary to the hypothesis, intergroup anxiety in the experimental group ( $M$ $=29.91, S D=8.36$ ) was lower than that of the control group $(M=34.19, S D=6.86)$.

\section{Discussion}

Our t-test on manipulation check showed that the reading passages we presented to manipulate intergroup threat have worked as expected, i.e., inducing general anxiety and sadness in participants in the experimental group. Nevertheless, ANCOVA showed that after controlling the positive intergroup contact, intergroup anxiety in the experimental group was lower instead of higher than that of the control group. This is an interesting finding to discuss. In order to identify some factors that might lead to this result, we looked back at our theoretical foundations, evaluated our experiment, as well as conducted some follow-up interviews with some of our respondents. We conducted the interview with eight (8) selected participants (i.e. those from the experimental group but showed low intergroup anxiety scores), via WhatsApp chat. The main question asked is written below, and this main question would be followed by probing questions in response to the answers each participant provided.

"During the study, you were asked to read
three texts with the topics about a protest,
a boycott, and health. After the reading
passages, you were asked to imagine
working in a team with non-Chinese people
you did not know and asked to rate how
you felt about it. My data shows that you
were relatively unafraid, not anxious, and
quite comfortable. Why were you relaxed
and not feeling worried when you
imagined working with unfamiliar non-
Chinese people despite having read the
passages describing the potential conflicts
between Chinese ethnic and indigenous
people of Indonesia?"

Based on the evaluation processes above, we offer several possible explanations about the unexpected result. These possibilities are discussed below; for ease of reading, we use two headings: intergroup trust and social desirability. Some methodological issues are also discussed. 
Table 1

Scores of Intergroup Anxiety, Positive Intergroup Contact, and Manipulation Check in the Control and Experimental Groups

\begin{tabular}{lcccccc}
\hline \multicolumn{1}{c}{ Variables } & Min & Max & \multicolumn{2}{c}{ Experiment } & \multicolumn{2}{c}{ Control } \\
\hline & & & $M$ & $S D$ & $M$ & $S D$ \\
\cline { 3 - 6 } & & & & & & \\
Manipulation check & 3 & 15 & 11.09 & 2.506 & 6.28 & 1.76 \\
Intergroup anxiety & 13 & 65 & 29.91 & 8.36 & 34.19 & 6.86 \\
Positive intergroup & 20 & 100 & 76.94 & 11.21 & 74.16 & 16.32 \\
contact & & & & & & \\
\hline
\end{tabular}

\section{Intergroup trust}

The first possible explanation is concerning the link between general anxiety and intergroup anxiety. The passages indeed induced general anxiety as shown by the difference of manipulation check between the two groups; however, it was not anticipated that this anxiety level measured by our items (sad, anxious, and happy (reversed)) might not directly lead to intergroup anxiety. This anxiety from the manipulation check was probably too general and was just an instant reaction from the readings. As suggested by Gernsbacher et al. (1992), reading could induce emotional reactions as a consequence of readers' understanding of what is happening in the narrative. However, this emotional response might not be permanent and could rather be a transient state associated with specific events or characters in the narrative (Vega, 1996). Thus, it is possible that this instant emotion does not necessarily transform into intergroup anxiety.

From further literature, we found that the absence of the link between the general anxiety and intergroup anxiety above could be attributed to a variable called intergroup trust, which was unfortunately not included in this study. Intergroup trust is defined as a positive expectation of out-group behavior toward in-groups (Lewicki et al., 1998). From our interview, five participants stated that the news snippet containing the intergroup threats they read did not affect their intergroup anxiety because in real life their interaction experience with indigenous Indonesians has been very positive (please note that most of the participants reported very positive contact experience with non-Chinese Indonesians; $84 \%$ of subjects scored higher than the hypothetical mean in positive intergroup contact). Further, four out of eight interviewed participants stated that their positive experiences in the intergroup interacttions so far have made them believe (trust) that indigenous members they encountered everyday are actually good people who are non-discriminatory and willing to accept them. One participant expressed his intergroup trust by stating that racial discrimination is not a practice he believes exist in current daily lives. Tam et al. (2009), through their first phase of the study, found that trust is a substantial concept for intergroup peace as it mediates the positive effect of intergroup contact on positive behavioral tendencies toward out-group. Moreover, in a further study they separately compared trust and attitudes as the predictor of behavior tendencies toward outgroup members, trust came out as the strongest predictor. In accordance with that, Turner et al. (2010) also emphasize that the success in achieving positive intergroup contact is very related to the individuals' ability to build trust among each other.

Kenworthy and his colleagues (2016) found that intergroup trusts reduced negative emotions towards out-groups. According to Tam et al. (2009), with high trust toward out-groups, people would keep positive expectations of their out-groups and therefore they would not easily feel anxious about interacting with the out-group members, even in a threatening situation. In addition, participants in this study were college students, which means they are relatively knowledgeable and used to thinking critically and openly. When reading the threat-inducing passages, they might have not immediately believed that the contents of the texts are facts. Thus even though reading the texts raised some feelings of anxiety, it did not immediately provoke intergroup anxiety.

Another demographic factor that might relate to intergroup results is the participants' age, which was between 18 and 24 years old or born between 1992 and 1998. The last racial conflict involving Chinese Indonesians occurred in May 1998. Thereafter the condition of intergroup relations in Indonesia was relatively peaceful until the end of 2014. It can be stated that participants were still very young (below 7 years old) when the 1998 riot happened and subsequently they grew up during a fairly peaceful period. Moreover, Gus Dur's pro-Chinese policy introduced in 2001 has improved considerably Chinese Indonesians' lives; i.e. ensuring 
the freedom of expression for Chinese ethnic groups and protecting the group against systemic discriminations. Put simply, participants of this experiment have not experienced the inter-ethnic conflicts in the first place and therefore might not easily internalize the intergroup threat. The results could possibly differ should we have involved older participants.

\section{Social desirability}

The issue of intergroup relationships between indigenous and Chinese ethnic Indonesians is a sensitive issue in Indonesian history and therefore the possibility that the data may be affected by social desirability should not be ignored. As stated by Cherry et al. (2015), the more the measured action is deemed as normative or sensitive, the more it might be affected by social desirability.

Past studies also confirmed this notion. Schweitzer et al. (2005) studied intergroup threat and the attitude towards refugees in Australia in the time when social and political issues on refugees in Australia drew Australian public and media attention. They reported that their subjects' social desirability contributed around $8 \%$ to the variance of the Australian community's attitude towards refugees. After controlling for social desirability, the intergroup threat was in fact predicted $95 \%$ of the attitude towards refugees in Australia. We thus admit that there is a possibility that the scores of intergroup anxiety reported by our participants might not be honest scores. Moreover, it is possible that the experimental group reported higher scores because they wanted to show that they were "just fine" (not feeling any negative feelings including anxiety) after reading the passages.

Furthermore, subjects might have been reluctant to admit that they felt anxious when facing the members of out-groups because being anxious might be considered as showing their personal weakness and the lack of competence in social interactions. Moreover, the social and political issues concerning Chinese ethnicity, especially in current Indonesia's context that has been widely discussed since the 2014 Indonesian Presidential Election may also prevent the subjects from giving honest answers. All in all, the fact that this research was conducted in collectivistic cultures and of sensitive issues may lead to higher social desirability.

The tendency for social desirability is related to culture. As Middleton and Jones (2000) found from their research, individuals originated from collectivist Eastern cultured countries such as Hong Kong, Singapore, Thailand, Taiwan, Japan, and China showed higher tendency to deny socially undesirable trait and admitted socially desirable trait compared with those originated from individualistic western cultured countries, such as The US. This may be due to collectivistic values that highly appreciate the harmony of interdependent relationships in the community. Individuals that originated from collectivist culture are expected not to show emotion openly so that their self-weaknesses are not apparent and the social harmony in the society could be well maintained (Kramer et al., 2002).

Apart from the above issues, we also identified several aspects related to methods that need to be improved. First, we found one of the eight subjects interviewed stated that he did not feel anxious when reading the threat-inducing passages because he actually identified himself more as an Indonesian citizen rather than as a Chinese Indonesian. This implies his social identification as an "in-group member of Indonesian citizens" rather than as an "out-group for indigenous Indonesians" and reminds us that we should have been controlling the social identity of participants, especially due to the demographic characteristic of our participants as explained previously.

Social identity is an individual selfconcept based on the social group membership perceived by the individual (Hogg \& Vaughan, 2002; Tajfel \& Turner, 1979). Stephan (2014) states that individuals who identify themselves strongly against a social group (nation, ethnicity, religion, or gender) may experience intergroup anxiety when interacting with members of a social group that is very different from their group. This statement was confirmed by previous research conducted by Aberson and Gaffney (2009) on 389 undergraduate students in the United States. In their research, Aberson and Gaffney (2009) found that one of the antecedents of perceived threat is the in-group identification of individuals. Individuals' who have strong identification towards their in-group (including racial/ethnic group) would perceive stronger threats from the outgroups. Based on these findings, there is a possibility that the subjects' in-group identification as citizens of Indonesia was stronger than their ingroup identification as a member of the Chinese ethnic group, and this made the exposure of intergroup threats through the reading passages did not affect their intergroup anxiety.

Second, the threat-inducing reading passages that we used in this experiment have been validated by expert judgments from two experts in the field of experimental psychology and social psychology. However, both experts were of Javanese instead of Chinese ethnicity. It is possible that experts from the Chinese ethnic background would suggest different opinions regarding the 
passages. For future research, the validation process should involve experts of Chinese ethnic background.

\section{Conclusion and Future Direction}

From this study, it can be concluded that after controlling for positive intergroup contact, intergroup anxiety was not higher in the group receiving intergroup threat. We presume that this result could be explained by: (1) the absence of the link between general anxiety (as provoked by the readings) and intergroup anxiety, which may be related to intergroup trust, and (2) social desirability. Future research should test this presumption. Furthermore, we also discussed that the next study should control subjects' social identity and involve experts with Chinese ethnicity to review the threat manipulations. With all the notes above, however, we still believe that this study has offered a substantial and meaningful contribution in understanding intergroup relationships in Indonesia, especially those involving the group of Chinese ethnicity.

\section{Bibliography}

Aberson, C. L. (2015). Positive intergroup contact, negative intergroup contact, and threat as predictors of cognitive and affective dimensions of prejudice. Group Processes \& Intergroup Relations, 18(6), 743-760. https://doi.org/10.1177/136843021455669 9

Aberson, C. L. \& Gaffney, A. M. (2009). An integrated threat model of explicit and implicit attitudes. European Journal of Social Psychology, 39(5), 808-830. https://doi.org/10.1002/ejsp.582

Allport, G. W. (1954). The nature of prejudice. Addison-Wesley

Amodio, D. M. \& Hamilton, H. K. (2012). Intergroup anxiety effects on implicit racial evaluation and stereotyping. Emotion, 12(6), 1273-1280. http://doi.org/10.1037/a0029016

Aziz, M. (2016). Gus Dur, Tionghoa, dan kepemimpinan. Gusdurian. Retrieved January 17, 2017, from https://www.gusdurian.net/id/article/allcategories/Gus-Dur-Tionghoa-danKepemimpinan/

Britt, T. W., Bonieci, K. A., Vescio, T. K., Biernat, M., \& Brown, L. M. (1996). Intergroup anxiety: A person $\mathrm{x}$ situation approach. Personality and Social Psychology Bulletin, 22(11), 1177-1188. http://doi.org/

10.1177/01461672962211008
Cherry, K. E., Allen, P. D., Denver, J. Y., \& Holland, K. R. (2015). Contributions of social desirability to self-reported ageism. Journal of Applied Gerontology, 34(6), 712-733. https://doi.org/10.1177/073346481348498 4

Davis, M. D., \& Stephan, W. G. (2011). Electromyographic analyses of responses to intergroup threat. Journal of Applied Social Psychology, 41(1), 196-218. https://doi.org/10.1111/j.15591816.2010.00709.x

Dhani, A. (2016). Rasisme terhadap etnis Tionghoa dari masa ke masa [The racism towards Chinese Indonesians from time to time]. Tirto. Retrieved May 5, 2020, from https://tirto.id/rasisme-terhadap-etnistionghoa-dari-masa-ke-masa-bZQN

Dhont, K., \& Van Hiel, A. (2012). Intergroup contact buffers against the intergenerational transmission of authoritarianism and racial prejudice. Journal of Research in Personality, 46(2), 231-234. https://doi.org/10.1016/j.jrp.2011.12.008

Gernsbacher, M. A., Goldsmith, H. H., \& Robertson, R. R. (1992). Do readers mentally represent characters' emotional states? Cognition \& Emotion, 6(2), 89-111. https://doi.org/ $10.1080 / 02699939208411061$.

Herman. (2016). Telkomsel kampanyekan penggunaan internet sehat [Telkomsel campaign for the healthy use of internet]. BeritaSatu. Retrieved October 20, 2016, from https://www.beritasatu.com/iptek/367419telkomsel-kampanyekan-penggun\%20aaninternet-sehat.html

Hogg, M. A., \& Vaughan, G. M. (2002). Social psychology: An introduction (3rd ed.). Prentice Hall.

Hutchison, P., \& Rosenthal, H. E. (2011). Prejudice against Muslims: Anxiety as a mediator between intergroup contact and attitudes, perceived group variability and behavioural intentions. Ethnic and Racial Studies, 34(1), 40-61. https://doi.org/10.1080/014198710037633 12

Kebidjaksanaan Jang Menjangkut Warga Negara Indonesia Keturunan Asing, Keputusan Presiden Pasal 5 No. 240 (1967). https://peraturan.bkpm.go.id/jdih/userfiles /batang/KepPres_240_1967.pdf

Islam, M. R., \& Hewstone, M. (1993). Dimensions of contact as predictors of intergroup anxiety, perceived out-group variability, and outgroup attitude: An integrative model. Personality and Social Psychology Bulletin, 19(6), 
https://doi.org/10.1177\%2F014616729319 6005

Isnaeni, H. F. (2010). Duka warga Tionghoa [The grief of the Chinese (Indonesians)]. Historia. Retrieved May 2, 2020, from http://historia.id/modern/duka-wargationghoa

Kenworthy, J. B., Voci, A., Al Ramiah, A., Tausch, N., Hughes, J., \& Hewstone, M. (2016). Building trust in a postconflict society: An integrative model of cross-group friendship and intergroup emotions. Journal of Conflict Resolution, 60(6), 1041-1070. https://doi.org/10.1177\%2F002200271456 4427

Kinanti, A. A. (2016). Mau punya tubuh sehat dan bugar jangan lupa rumus 5S [Want to have healthy and fit body, don't forget the $5 S$ formula]. Detik. Retrieved October 11, 2016, from https://health.detik.com/beritadetikhealth/d-3222193/mau-punya-tubuhsehat-dan-bugar-jangan-lupa-rumus-5s

Kramer, E. J., Kwong, K., Lee, E., \& Chung, H. (2002). Cultural factors influencing the mental health of Asian Americans. Western Journal of Medicine, 176(4), 227-231.

Kwartanada, D. (2015). Introduction (W. Alhaziri, Trans.). In P. Carey (Ed.), Orang Cina, bandar tol, candu, \& Perang Jawa: Perubahan persepsi tentang Cina (1755-1825). Komunitas Bambu.

Lewicki, R. J., McAllister, D. J., \& Bies, R. J. (1998). Trust and distrust: New relationships and realities. Academy of management Review, 23(3), 438-458. https://doi.org/ $10.2307 / 259288$

Littleford, L. N., Wright, M. O. D., \& Sayoc-Parial, M. (2005). White students' intergroup anxiety during same-race and interracial interactions: A multimethod approach. Basic and Applied Social Psychology, 27(1), 85-94. https://doi.org/ 10.1207/s15324834basp2701_9

Mackie, D. M., Devos, T., \& Smith, E. R. (2000). Intergroup emotions: Explaining offensive action tendencies in an intergroup context. Journal of Personality and Social Psychology, 79(4), 602. https://doi.org/10.1037//00223514.79.4.602

Middleton, K. L., \& Jones, J. L. (2000). Socially desirable response sets: The impact of country culture. Psychology \& Marketing, 17(2), 149-163.

https://doi.org/10.1002/(SICI)1520-

6793(200002)17:2\%3C149::AID-

MAR6\%3E3.0.CO;2-L

Mustamin. (2006). Kerawanan kerusuhan etnis Bugis-Makassar dan Cina di kotamadya Makassar, Sulawesi Selatan. Center for
Religious and Cross-Cultural Studies, Universitas Gadjah Mada.

Octama, C. I. (2016). Judika nikmati peran ayah [Judika enjoyed fatherly role]. BeritaSatu. Retrieved May 10, 2020, from https://www.beritasatu.com/seleb/366478judika-nikmati-peran-ayah.html

Paolini, S., Hewstone, M., Cairns, E., \& Voci, A. (2004). Effects of direct and indirect crossgroup friendships on judgments of Catholics and Protestants in Northern Ireland: The mediating role of an anxiety-reduction mechanism. Personality and Social Psychology Bulletin, 30(6), 770-786. https://doi.org/10.1177/014616720326284 8

Pettigrew, T. F., \& Tropp, L. R. (2008). How does intergroup contact reduce prejudice? Metaanalytic tests of three mediators. European journal of social psychology, 38(6), 922-934. https://doi.org/10.1002/ejsp.504

Prihartanti, N., Taufik, \& Thoyibi, M. (2009). Mengurai akar kekerasan etnis pada masyarakat pluralis. Jurnal Penelitian Humaniora, 10(2), 107-120. https://publikasiilmiah.ums.ac.id/handle/11 $617 / 643$

Putra, I. E. (2016). Representations and discourse about religion and Chinese descendants in 2012 Jakarta's election. The Qualitative Report, 21(10), 1799-1816. Retrieved from https://nsuworks.nova.edu/tqr/vol21/iss10 $/ 4$

Rahman, N. E. (2013). Konflik dan kecemburuan sosial antara etnis Tionghoa dan masyarakat Pandhalungan di daerah Besuki-Situbondo. Paper presented at the Prosiding The 5 th International Conference on Indonesian Studies:"Ethnicity and Globalization.

Riek, B. M., Mania, E. W., \& Gaertner, S. L. (2006). Intergroup threat and outgroup attitudes: A meta-analytic review. Personality and Social Psychology Review, 10(4), 336-353. https://doi.org/10.1207/s15327957pspr10 04_4

Sanjatmiko, P. (1993). Orang keturunan Cina di Tangerang: suatu kajian tentang faktor-faktor yang mendorong dan menghambat proses asimilasi antara penduduk golongan etnik keturunan Cina terhadap penduduk golongan etnik pribumi.

Schweitzer, R., Perkoulidis, S., Krome, S., Ludlow, C., \& Ryan, M. (2005). Attitudes towards refugees: The dark side of prejudice in Australia. Australian Journal of Psychology, 57(3), 170-179. https://doi.org/ 10.1080/00049530500125199 
Semyonov, M., Raijman, R., Tov, A. Y., \& Schmidt, P. (2004). Population size, perceived threat, and exclusion: A multiple-indicators analysis of attitudes toward foreigners in Germany. Social Science Research, 33(4), 681-701. https://doi.org/10.1016/j.ssresearch.2003.1 1.003

Shelton, J. N., \& Richeson, J. A. (2006). Interracial interactions: A relational approach. Advances in experimental social psychology, 38, 121-181. https://doi.org/10.1016/S00652601(06)38003-3

Stephan, W. G. (2014). Intergroup anxiety: Theory, research, and practice. Personality and Social Psychology Review, 18(3), 239-255. https://doi.org/10.1177\%2F108886831453 0518

Stephan, W. G., Renfro, C. L., \& Davis, M. D. (2008). The role of threat in intergroup relations. In U. Wagner, L. R. Tropp, G. Finchilescu \& C. Tredoux (Eds.), Improving intergroup relations: building on the legacy of Thomas $F$. Pettigrew (pp. 55-72). https://doi.org/ 10.1002/9781444303117.ch13

Stephan, W. G., \& Stephan, C. W. (1985). Intergroup anxiety. Journal of social issues, 41(3), 157-175. https://doi.org/10.1111/j.15404560.1985.tb01134.x

Stephan, W. G., Ybarra, O., \& Morrison, K. R. (2009). Intergroup threat theory. In T. Nelson (Ed.), Handbook of prejudice (pp. 43-59). Lawrence Erlbaum.

Suryadinata, L. (2002). Negara dan etnis Tionghoa: Kasus Indonesia. LP3ES.
Suryadinata, L. (2019). Indonesia's Tionghoa tensions: Revival of identity politics against Indonesia's ethnic Chinese. StraitsTimes. Retrieved May 15, 2020, from https://www.straitstimes.com/opinion/indo nesias-tionghoa-tensions

Tajfel, H., \& Turner, J. C. (1979). An Integrative Theory of Intergroup Conflict. In W. G. Austin \& S. Worchel (Eds.), The social psychology of intergroup relations (pp. 33-47). Brooks/Cole.

Tam, T., Hewstone, M., Kenworthy, J., \& Cairns, E. (2009). Intergroup trust in Northern Ireland. Personality and Social Psychology Bulletin, 35(1), 45-59. https://doi.org/10.1177\%2F014616720832 5004

Trawalter, S., Adam, E. K., Chase-Lansdale, P. L., \& Richeson, J. A. (2012). Concerns about appearing prejudiced get under the skin: Stress responses to interracial contact in the moment and across time. Journal of Experimental Social Psychology, 48(3), 682693.

https://doi.org/10.1016\%2Fj.jesp.2011.12.0 03

Turner, R. N., Hewstone, M., Swart, H., Tam, T., Myers, E., \& Tausch, N. (2010). Promoting intergroup trust among adolescents and young adults. In K. J. Rotenberg (Ed.), Trust and Trustworthiness during Childhood and Adolescence (pp. 295-321). Cambridge University Press.

Vega, M. (1996). The representation of changing emotions in reading comprehension. Cognition \& Emotion, 10(3), 303-322. https://doi.org/10.1080/026999396380268 


\section{Appendix 1. Intergroup anxiety scale}

Bayangkan sebuah situasi ketika Anda harus bekerja dalam sebuah tim. Tim tersebut seluruhnya beranggotakan orang-orang dari etnis asli Indonesia Non Tionghoa yang belum pernah Anda kenal sebelumnya. Bagaimana kira-kira perasaan Anda? Indikasikan dalam skala berikut ini. *

Saya akan merasa: (1) Sama Sekali Tidak, (5) Sangat. Contoh: Pada kata 'takut', menandai angka 1 berarti Anda merasa sangat tidak takut, sedangkan menandai angka 5 berarti Anda merasa sangat takut.

$\begin{array}{lllll}\begin{array}{c}\text { Sama Sekali } \\ \text { Tidak }\end{array} & 2 & 3 & 4 & \begin{array}{c}5- \\ \text { Sangat }\end{array}\end{array}$

\begin{tabular}{|c|c|c|c|c|}
\hline Takut & 0 & 0 & O & 0 \\
\hline Bersahabat & 0 & 0 & 0 & 0 \\
\hline Ragu & 0 & 0 & 0 & 0 \\
\hline Nyaman & 0 & 0 & 0 & 0 \\
\hline Kuatir & 0 & 0 & 0 & 0 \\
\hline Percaya & 0 & 0 & 0 & O \\
\hline Terancam & 0 & O & O & 0 \\
\hline Percaya Diri & O & 0 & 0 & 0 \\
\hline Canggung & 0 & $\mathrm{O}$ & 0 & 0 \\
\hline Tenang & 0 & 0 & 0 & 0 \\
\hline Cemas & 0 & O & 0 & 0 \\
\hline Santai & 0 & 0 & 0 & 0 \\
\hline Risih & 0 & 0 & 0 & 0 \\
\hline
\end{tabular}




\section{Appendix 2. Positive intergroup contact scale}

Di bawah ini terdapat beberapa pernyataan di mana Anda diminta untuk memberikan evaluasi sejauh mana kontak Anda dengan orang-orang etnis Non Tionghoa bersifat bersahabat, menyenangkan, konstruktif (saling membangun) dan memberikan pengalaman positif. Untuk setiap kata sifat, terdapat 5 (lima) pilihan jawaban yang disediakan yaitu "Sangat Tidak Sesuai" (STS) hingga "Sangat Sesuai" (SS). Semakin ke kanan kolom yang Anda pilih, semakin sesuai kata sifat tersebut dengan kenyataan yang Anda alami.

Pada saat Anda TK, pada umumnya kontak Anda dengan orang-orang dari etnis Asli Indonesia Non Tionghoa bersifat:

$\begin{array}{cccc}\text { Sangat } & \text { Tidak } & \text { Sesuai } & \text { Sangat } \\ \text { Tidak } & \text { Sesuai } & & \text { Sesuai } \\ \text { Sesuai } & & & \end{array}$

\begin{tabular}{|c|c|c|c|c|}
\hline Bersahabat & 0 & 0 & 0 & 0 \\
\hline Menyenangkan & 0 & 0 & 0 & 0 \\
\hline Konstruktif & 0 & O & 0 & O \\
\hline $\begin{array}{l}\text { Memberi Pengalaman } \\
\text { Positif }\end{array}$ & 0 & 0 & 0 & 0 \\
\hline
\end{tabular}

Pada saat Anda SD, pada umumnya kontak Anda dengan orang-orang dari etnis Asli Indonesia Non Tionghoa bersifat:

\begin{tabular}{|c|}
\hline Sanga \\
\hline Tidak \\
\hline
\end{tabular}

\begin{tabular}{|c|c|c|c|c|}
\hline Bersahabat & 0 & 0 & 0 & 0 \\
\hline Menyenangkan & 0 & 0 & 0 & 0 \\
\hline Konstruktif & 0 & 0 & 0 & 0 \\
\hline $\begin{array}{l}\text { Memberi Pengalaman } \\
\text { Positif }\end{array}$ & 0 & 0 & 0 & 0 \\
\hline
\end{tabular}

Pada saat Anda SMP, pada umumnya kontak Anda dengan orang-orang dari etnis Asli Indonesia Non Tionghoa bersifat:

\begin{tabular}{|c|c|c|}
\hline Sangat & Tidak & Sesuai \\
\hline
\end{tabular}

$\begin{array}{lllll}\text { Bersahabat } & 0 & 0 & 0 & 0\end{array}$

$\begin{array}{llllll}\text { Menyenangkan } & 0 & 0 & 0 & 0 & 0\end{array}$ 


\begin{tabular}{|c|c|c|c|c|c|}
\hline Konstruktif & 0 & 0 & 0 & 0 & 0 \\
\hline $\begin{array}{l}\text { Memberi Pengalaman } \\
\text { Positif }\end{array}$ & 0 & 0 & 0 & 0 & 0 \\
\hline \multicolumn{6}{|c|}{$\begin{array}{l}\text { Pada saat Anda SMA, pada umumnya kontak Anda dengan orang-orang dari etnis Asl } \\
\text { Indonesia Non Tionghoa bersifat: }\end{array}$} \\
\hline & $\begin{array}{c}\text { Sangat } \\
\text { Tidak } \\
\text { Sesuai }\end{array}$ & $\begin{array}{l}\text { Tidak } \\
\text { Sesuai }\end{array}$ & & Sesuai & $\begin{array}{l}\text { Sangat } \\
\text { Sesuai }\end{array}$ \\
\hline Bersahabat & 0 & 0 & 0 & 0 & 0 \\
\hline Menyenangkan & 0 & 0 & 0 & 0 & 0 \\
\hline Konstruktif & 0 & 0 & 0 & 0 & 0 \\
\hline $\begin{array}{l}\text { Memberi Pengalaman } \\
\text { Positif }\end{array}$ & O & 0 & 0 & 0 & O \\
\hline \multicolumn{6}{|c|}{$\begin{array}{l}\text { Pada saat Anda Kuliah, pada umumnya kontak Anda dengan orang-orang dari etnis Asl } \\
\text { Indonesia Non Tionghoa bersifat: }\end{array}$} \\
\hline & $\begin{array}{c}\text { Sangat } \\
\text { Tidak } \\
\text { Sesuai }\end{array}$ & $\begin{array}{l}\text { Tidak } \\
\text { Sesuai }\end{array}$ & & Sesuai & $\begin{array}{l}\text { Sangat } \\
\text { Sesuai }\end{array}$ \\
\hline Bersahabat & 0 & 0 & 0 & O & O \\
\hline Menyenangkan & 0 & 0 & 0 & 0 & 0 \\
\hline Konstruktif & 0 & 0 & 0 & 0 & 0 \\
\hline $\begin{array}{l}\text { Memberi Pengalaman } \\
\text { Positif }\end{array}$ & 0 & 0 & 0 & 0 & 0 \\
\hline
\end{tabular}

